\title{
Pascal ROBERT, Mnémotechnologies
}

Paris, Éd. Hermès-Lavoisier, coll. Communication, médiation et construits sociaux, 2010, $400 \mathrm{p}$.

\section{David Forest}

\section{(C) OpenEdition}

\section{Journals}

Édition électronique

URL : http://journals.openedition.org/questionsdecommunication/326

DOI : 10.4000/questionsdecommunication.326

ISSN : 2259-8901

\section{Éditeur}

Presses universitaires de Lorraine

\section{Édition imprimée}

Date de publication : 1 décembre 2010

Pagination : 319-320

ISBN : 978-2-8143-0056-9

ISSN : $1633-5961$

\section{Référence électronique}

David Forest, "Pascal Roвert, Mnémotechnologies », Questions de communication [En ligne], 18 | 2010, mis en ligne le 07 décembre 2011, consulté le 25 septembre 2020. URL : http://

journals.openedition.org/questionsdecommunication/326 ; DOI : https://doi.org/10.4000/ questionsdecommunication.326

Ce document a été généré automatiquement le 25 septembre 2020.

Tous droits réservés 


\section{Pascal ROBERT, Mnémotechnologies}

Paris, Éd. Hermès-Lavoisier, coll. Communication, médiation et construits sociaux, 2010, $400 \mathrm{p}$.

David Forest

\section{RÉFÉRENCE}

Pascal ROBERT, Mnémotechnologies

Paris, Éd. Hermès-Lavoisier, coll. Communication, médiation et construits sociaux, 2010, $400 \mathrm{p}$.

\section{NOTE DE L'ÉDITEUR}

L'auteur n'a pas souhaité donner son accord pour la diffusion électronique de son article.

INDEX

oeuvrecitee Mnémotechnologies - (Pascal Robert, 2010) 
AUTEURS

DAVID FOREST

LAS, université Rennes 2

forestdavid@orange.fr 